ISSN 2518-1521 (Online), ISSN 2226-2830 (Print)

ВІСНИК МАРІУПОЛЬСЬКОГО ДЕРЖАВНОГО УНІВЕРСИТЕТУ

СЕРІЯ: ІСТОРІЯ. ПОЛІТОЛОГІЯ, 2020, ВИП. 28-29

УДК 329.7-055.2(477.4)”189/191”

\title{
V. Motuz
}

\section{THE HISTORY OF THE TRANSFORMATION OF WOMEN OF NADDNIPRYANSK UKRAINE FROM AN OBJECT INTO A SUBJECT OF THE POLITICAL PROCESS: FROM IDEA TO PRACTICAL IMPLEMENTATION}

The article substantiates the theoretical and practical foundations of the development of the women's movement in Naddnipryan Ukraine in the conditions of active politicization of society in the late 19th - early 20th century. When the object of the study is the increase by women from Naddnipryanskaya Ukraine of their social status in society, and the subject is their transformation from an object into a subject of political activity. This process is revealed from the standpoint of the influence of the politicization of Ukrainian society in the late 19th-early 20th century on the movement of socially active women in Nadnipryansk Ukraine towards achieving the modernization of the system of power and management from the point of view of gender equality and is presented as a transitional stage to this.

Keywords: woman, women's history, women's movement, women's movement in the Dnieper Ukraine of the late XIX-early XX centuries, society, Ukrainian society, politicization of Ukrainian society in the late XIX-early XX centuries

DOI 10.34079/2226-2830-2020-10-28-29-99-108

Formulation of the problem. The origin of the women's movement in Ukraine goes back to the middle of the 19th century. Its history is divided into several stages, each of which has its own characteristics and historical significance. In our opinion, one of the key stages in the development of the women's movement in Ukraine is the end of the 19th - the beginning of the 20th century. It is characterized by active politicization in the Ukrainian lands of both empires, primarily in the Naddnipryan Ukraine. It was at this historical stage in the development of the Ukrainian women's movement in Naddnipryan Ukraine that its representatives, along with their Western Ukrainian and Russian colleagues, outlined another vector of their activities - the achievement of modernization of the system of power and management from the standpoint of gender equality. However, unlike them, women in Naddnipryan Ukraine were the first to change their social and legal status, turning from an object into a subject of the political process, thereby initiating the next stage of its development.

Noting the historical stage in the development of the women's movement in Naddnipryansk Ukraine (late XIX - early XX century), as an intermediate stage between the stage when it was noted about the need for women's access to all spheres of social life of society (mid-80s of the XIX century) and the stage when women both de jure and de facto, they joined in the mastery of the last "not taken" by them, until March 1917, "heights" - this is obtaining political rights and access to state leadership.

It should be noted that the key event that strengthened the desire of women to have political rights was another revolution - the First Russian bourgeois-democratic revolution of 1905 - 1907 , or rather October 1905. It was then, under pressure from society, that the Manifesto of Nicholas II was proclaimed, which introduced empire a new constitutional system and as a body of people's 
ISSN 2518-1521 (Online), ISSN 2226-2830 (Print)

ВІСНИК МАРІУПОЛЬСЬКОГО ДЕРЖАВНОГО УНІВЕРСИТЕТУ

СЕРІЯ: ІСТОРІЯ. ПОЛІТОЛОГІЯ, 2020, ВИП. 28-29

representation - the Russian State Duma. The Duma Election Procedure Act, published in December 1905, granted voting rights only to men (Шевченко, 2013, с.131). Women found themselves in the category of citizens who did not have political powers. From this moment, in the Russian Empire, the question arises about the civil equality of women and about granting them the right to elect and be elected to government bodies. The solution to this issue was primarily concerned with women's organizations, including those from Naddnipryansk Ukraine, which actively advocated the idea of gender equality in society. To do this, they began to use various forms of collective action - meetings, petitions to government bodies, rallies and the like.

Analysis of research and publications. Our historiographic analysis of the process of transformation of women in Naddnipryansk Ukraine into a subject of political activity demonstrates that the issue we are researching has not yet been actualized as a complex scientific problem. And this is despite the fact that there is a significant layer of scientific literature on it, which explores various aspects of this historical phenomenon.

The result of the review of scientific research is the statement that, in its final form, the process of transforming women of Nadnipryan Ukraine into a subject of political activity has not yet been covered, but some of its aspects are analyzed in the context of various issues that scientists have dealt with. In particular, in scientific works I. Andrusyak (Андрусяк, 2014), S. Bilosorochka (Білосорочка, 2018), M. Bogachevskaya-Khomyak (Богачевська-Хомяк, 1995), V. Dobrovolskaya (Добровольська, 2017), L. Smolyar (Смоляр, ред., 1999), К. Kobchenko (Кобченко, 2012), N. Lobko (Лобко, 2016), A. Nestertsova-Sobakar (Нестерцова-Собакарь, 2016), N. Oliynyk (Олійник, 2013), L. Petryshyna (Петришина, 2016), L. Potapyuk (Потапюк, 2015), S. Siropolko (Сірополко, 2001), I. Stashin (Сташин, 2008), I. Fatkhutdinova (Фатхутдінова, 2015), M. Shevchenko (Шевченко, 2013), L. Yatsenko (Яценко, 2008) and other researchers.

So, despite the significant achievements of scientists in the study of the issue of politicization of the women's movement in the Ukrainian lands in the late 19th - early 20th centuriy and their unquestioning scientific significance, the history of the transformation of women in Nadnipryansk Ukraine from an object into a subject of the political process is presented fragmentarily and requires a separate comprehensive study.

The purpose of this article is to highlight the key stage in the development of the women's movement in Naddnipryan Ukraine, during which not only its politicization took place, but also a support was formed for the further advancement of women in such an important component of the public sphere of society as public administration.

Presentation of the main material. If at the previous stage of its development the women's movement of Naddnipryansk Ukraine had significant support from the democratically-minded men of the region, then in the 90s of the XIX century the paths of the progressive intelligentsia of Naddnipryansk Ukraine diametrically diverged on the basis of gender. Men supported the representatives of the women's movement as long as it fit within the boundaries of their understanding of the problem of women's emancipation. In the traditional male concept of equal rights and opportunities for women in the public sphere of society, there was only the right of women to higher education and their participation in social production (Андрусяк, 2014, с.12).

In the early 90 s of the XIX century, in the development of the women's movement in Naddnipryan Ukraine, transformations were outlined, which concerned the expansion of the sphere of social activity of women, the growth of their function and number, as well as some changes in its direction (Міщенко, 2011, с.113). 
ISSN 2518-1521 (Online), ISSN 2226-2830 (Print) ВІСНИК МАРІУПОЛЬСЬКОГО ДЕРЖАВНОГО УНІВЕРСИТЕТУ СЕРІЯ: ІСТОРІЯ. ПОЛІТОЛОГІЯ, 2020, ВИП. 28-29

In the first incomplete twenty years of the second stage - the 90s of the 19th century - 1908 - representatives of women's organizations of Naddnipryansk Ukraine participated in various international congresses and exhibitions, helped to attract women of the region to general civilization processes and significantly expanded women's ideas about effective ways and methods of struggle for their rights (Богачевська-Хомяк, 1995, с.229).

The corresponding understanding was formed on the basis of summary statistical data on the status of women in the Russian Empire, in particular in Naddnipryansk Ukraine, and familiarization of the participants of the women's movement in Naddnipryansk Ukraine with the experience of women fighting for their rights in the leading countries of the world at that time. All this made the representatives of the women's organizations of Naddnipryan Ukraine thoroughly analyze their previous activities and think about their future (Потапюк, 2015, c.21).

In the Ukrainian society of the late 19th century, there were many social problems associated with the women's issue. Trafficking in women and prostitution were among the priorities. Activists of the women's movement in Nadnipryan Ukraine were very worried about this problem. However, they understood that solving it only through the efforts of small women's organizations was an impossible mission. The next sore point was the lack of political rights among women who already had access to higher education and had the opportunity to earn independently (Міщенко, 2011, c.114).

The women's movement of Naddnipryansk Ukraine is changing the tactics of the struggle for their rights in the period we are considering. In particular, women's organizations actively cooperate not only in the Naddnipryansk Ukraine, but also with women's associations in other regions of the Russian Empire and Western Ukraine (Смоляр, ред., 1999, с.301). That is, the desire and actions to form a united front in the struggle of women for their interests became one of the features of the activities of the Ukrainian women's movement in the 90s of the XIX century.

Since that time, along with the already traditional activity of the women's movement in Naddnipryansk Ukraine - charitable, there is also a sociopolitical one. Therefore, in addition to charitable, professional, educational and clerical women's organizations there were also women's social and political associations. These organizations became imbued with the problem of women's political rights and moral and ethical issues, primarily related to the trafficking in women and prostitution (Олійник, 2013, с.78). So, the leading women's organizations of Naddnipryan Ukraine, who were concerned about these issues, were the Kiev and Odessa Society for the Defense of Women. At that time, these were influential societies with many members. These women's organizations have existed for over ten years, making efforts to protect the rights of women (Сташин, 2008, с.169).

The new slogan of the second stage of the activity of the Ukrainian women's movement in Naddnipryan Ukraine was: "Freedom and equality before the law of representatives of both sexes", which directly concerned the struggle of women for electoral rights (Нестерцова-Собакарь, 2016, c. 84).

When, as a result of the revolutionary democratic movement of the 90s of the XIX century, the issue of creating a Constitution and introducing universal suffrage in the Russian Empire was considered, women were not taken into account. That is, a woman as a future subject of the political process in the state was not considered (Яценко, 2008, с.388).

On the pages of the periodicals of that time, you will not find the sympathy and understanding that the idea of women's emancipation had during the initial stage of the women's movement in Nadnipryan Ukraine, namely in the 60s of the 19th century (Богачевська-Хомяк, 1995, с.233). 
The overwhelming majority of the male population of the Russian Empire did not see the need to endow women with political rights, in particular the right to elect and be elected to local government bodies, especially to parliament. In this connection, many newspaper articles of that period drew the attention of women to their natural purpose (Смоляр, ред., 1999, с.316).

This general civil rejection of the political rights of women became the circumstance that prompted socially active women who fought for the equalization of the state and legal status of women and men in society to create women's organizations. Thus, relying only on their own strength, women were engaged in asserting their rights (Олійник, 2013, с.79).

If we recall the initial stage of the women's movement in Naddnipryansk Ukraine, then during this period all the actions of women's organizations were within the framework of the law, and, for the most part, concerned charity and mutual assistance. Since the 90s of the 19th century, the women's movement in Naddnipryan Ukraine began to actively seek amendments to the legislative framework, where it concerned the civil and political rights of women (Нестерцова-Собакарь, 2016, c.92). That is, the women's movement of Naddnipryan Ukraine fought for the real participation of women in all spheres of society.

At the beginning of the twentieth century, such fans of the idea of equality in society began to be called "equal rights", although the Ukrainian society was also familiar with the concept of "feminism" and understood its essence. Therefore, the "equal rights" were considered in Naddnipryan Ukraine as a women's movement for providing women with favorable conditions and opportunities for their self-development, which acted in the interests of women themselves and society as a whole (Фатхутдінова, 2015, с.79).

You need to understand that the historical meaning of the term "feminism" is different from the modern one. So, Ukrainian feminists of Naddnipryan Ukraine, unlike their colleagues from Western Europe and North America, paid less attention to the private sphere of society (marriage and family issues), focusing on issues related to the participation of women in the public sphere of society (Сташин, 2008, с.172). In addition, Western feminists aimed their actions at separating from the male hierarchical system and, accordingly, creating their own, while ours tried not to create our own, but to use the existing one in their own interests (Богачевська-Хомяк, 1995, c.237).

We emphasize once again that feminist-minded women in the Naddnipryan Ukraine of the late 19th - early 20th centuries fought for gender equality in society (Кобченко, 2012, c.273).

However, the feminist movement was one of several ideological currents of the women's movement in Naddnipryan Ukraine. For example, in addition to equal rights, it also included revolutionaries: social democrats, anarchists, nihilists, etc. (Олійник, 2013, c.77). Unlike the latter, feminists were not associated with terror, choosing humane methods of struggle. They were guided by the "do no harm" principle. Acting within the framework of the existing system, the rivnopravks did not achieve a radical transformation of society, they sought to achieve the right to vote for women in a peaceful, reform way (Нестерцова-Собакарь, 2016, с.95).

As a result of the change in the sociopolitical situation in the Russian Empire for the beginning of the twentieth century - the Russian bourgeois-democratic revolution of 1905 - 1907 - democratic transformations began, the legalization of already existing parties and the legalization of a multi-party system, which led to the emergence of new women's organizations and their forms of struggle for their rights (Лобко, 2016, c.44). It should be pointed out that the Ukrainian women's movement at that time became more politicized and differentiated (Яценко, 2008, с.389).

One of the well-known women's organizations in Naddnipryan Ukraine at the beginning of the twentieth century was the Union of Equality of Women, which had its representations in many 
ISSN 2518-1521 (Online), ISSN 2226-2830 (Print)

cities of the region. This organization united women in the struggle for their civil, political and national rights. The most effective in this regard was the activity of the Poltava department of the Union, which was headed by a leading public figure, writer, ethnographer, publicist, sister of Mikhail Dragomanov and mother of Lesya Ukraine - Elena Pchilka (Білосорочка, 2018).

Also at this time, women's organizations were quite actively formed in Naddnipryan Ukraine. They operated both at educational institutions, in particular gymnasiums and higher female courses, and at various Ukrainian societies (Добровольська, 2017, с.58).

Another very significant feature of the second stage in the development of the women's movement in Naddnipryan Ukraine was the transition in the activities of women's organizations from single-profile to multi-profile. Thus, as a result of the spread of the idea of women's struggle for their political and civil rights among the women's movement in Naddnipryan Ukraine, many Ukrainian women's associations took up it, but did not abandon their core activities. This refers to charity, mutual assistance and education (Смоляр, ред., 1999, с.319).

The direct actions of the representatives of the women's movement in Naddnipryansk Ukraine of the period under study were associated with agitation against trafficking in women and prostitution; the admission of women to universities and the creation of Higher Courses for Women; appealing to the authorities of various levels and political parties with demands and justification for granting women political rights; support of workers' speeches, etc. (Петришина, 2016, c.17).

All of the above indicated by us testifies to a clear growth of the political consciousness of women in the Nadnipryan Ukraine. For example, during the growing revolutionary wave of demonstrations in 1905 in the Russian Empire, and in Naddnipryan Ukraine in particular, there was cooperation between the liberal democratic and social democratic currents of the women's movement. Their representatives united for a joint struggle for universal suffrage. Although, after the proclamation of the Manifesto of 1905, the paths of these two different ideological currents in the women's movement in Naddnipryansk Ukraine diverged. The discrepancy concerned the methods of achieving political rights and the understanding of why these rights were needed by a woman (Смоляр, ред., 1999, с.284).

Thus, the liberal democratic trend of the women's movement in Naddnipryan Ukraine advocated only the evolutionary path of achieving them, in contrast to the social democratic trend, which did not exclude a forced, revolutionary path. For example, if for the former to become a subject of political processes, having won universal suffrage, meant expanding their social capabilities, primarily in professional activity, then for proletarian women obtaining it was considered as a means of changing the sociopolitical system and the destruction of the capitalist mode of production with the establishment of a socialist one (Міщенко, 2011, c.114).

The social mobility of representatives of the Ukrainian women's movement at the beginning of the twentieth century is evidenced by their participation in the All-Russian Women's Congress, held on December 10 - 16, 1908 in St. Petersburg. Ukrainian representatives were not mere observers at the congress, they actively spoke out noting about women's and national problems. In particular, the documents of the congress recorded speeches with reports of representatives of the women's movement of Naddnipryansk Ukraine, their participation in all plenary sessions and sections of the congress, as well as about their proposals (Богачевська-Хомяк, 1995, с.251).

The historical significance of this congress was in the discovery for the general imperial society of the fact of the existence of an organized women's movement in Naddnipryan Ukraine. It identified the urgent problems of women and the strategic line of their struggle for political and civil rights. In addition, an attempt was made to unite women of different strata of society, material 
ISSN 2518-1521 (Online), ISSN 2226-2830 (Print)

ВІСНИК МАРІУПОЛЬСЬКОГО ДЕРЖАВНОГО УНІВЕРСИТЕТУ

СЕРІЯ: ІСТОРІЯ. ПОЛІТОЛОГІЯ, 2020, ВИП. 28-29

status and political views by such a common interest as combating the bias of society regarding the role and place of women in it (Кобченко, 2012, с.273). However, as it turned out later, this could not be done due to the existence of not only gender, but also socio economic inequality (Слюсаренко, Гусєв та Литвин, 2002, с.116). Another important consequence of its implementation was the impact on the political outlook of women.

During the period of government reaction, or as it is also called Stolypin, the surge of activity that the women's movement of Nadnipryansk Ukraine had during the Russian bourgeoisdemocratic revolution of 1905 - 1907 was replaced by a certain decline. However, despite the government's repressive measures against the revolutionaries, representatives of the women's movement in Nadnipryansk Ukraine, having gained colossal experience in the revolutionary period, continued, although not at full power, their activities (Смоляр, ред., 1999, с.315).

The novelty of this period in the development of the Ukrainian women's movement was the creation of women's associations of a new type - Women's Clubs (Потапюк, 2015, с.22).

These were independent organizations that were engaged in the protection of women's rights, were a mutual assistance fund for their members, and also a place for a pleasant pastime. They owned hostels, reading rooms, libraries, schools, canteens, labor bureaus, kindergartens, etc. The authoritative and largest organizations of this type turned out to be the Kiev women's general meeting and Kiev women's club (Петришина, 2016, с.17).

The corresponding women's associations represented the liberal democratic current of the women's movement in Naddnipryan Ukraine. Its members sent proposals to local government bodies to expand their political rights, for example, about getting the opportunity to elect and be elected to the city council and zemstvo (Фатхутдінова, 2015, с.79). They also fought for the admission of women to university studies and equality of wages, pensions and inheritance rights for both sexes (Нестерцова-Собакарь, 2016, с.116).

As for the latter, the women of the Russian Empire, including the Naddniprian Ukraine, won this right. So, already on June 3, 1912, the secondary position of women in the right to inheritance was eliminated (Кобченко, 2012, с.273). Another achievement of women's struggle in the private sphere of public life was the adoption of the law of March 12, 1914 on the right to separate spouses. In addition, the range of intellectual professions for which women gained access was expanded (Нестерцова-Собакарь, 2016, с.118).

Representatives of the women's movement in Naddnipryan Ukraine became delegates at the All-Russian Congress on Combating Trafficking in Women, which took place in 1910. and the AllRussian Congress on the Education of Women in 1913. We repeat once again that such activity, which was at the First All-Russian Women's Congress, was no longer observed (Сірополко, 2001, c.479).

At the first congress on combating trafficking in women, the activities of the Kiev Society for the Defense of Women, primarily its leader Vera Klyachkina, were noted. At the second congress, the Ukrainian women's organization "Kharkov Society for Mutual Assistance to Working Women" (Яценко, 2008, с.390) was praised.

The development of the women's movement in Naddnipryan Ukraine was significantly influenced by the First World War. Most of the Ukrainian women's organizations subordinated their activities to the needs of the front. For example, women's organizations opened courses for training sisters of mercy to work in hospitals and refugee shelters, sewed underwear for soldiers and provided free assistance to the military (Потапюк, 2015, с.22). 
ISSN 2518-1521 (Online), ISSN 2226-2830 (Print) ВІСНИК МАРІУПОЛЬСЬКОГО ДЕРЖАВНОГО УНІВЕРСИТЕТУ СЕРІЯ: ІСТОРІЯ. ПОЛІТОЛОГІЯ, 2020, ВИП. 28-29

At the same time, women's organizations did not forget about their main functions. They continued to help women find jobs, were engaged in charitable and educational activities, and also fought for them to obtain active and passive suffrage (Лобко, 2016, с.48).

Conclusions and suggestions. Summing up, we can say that, firstly, the period of activity of the women's movement in Naddnipryan Ukraine, which we are examining, which lasted from the 90s of the XIX century until the beginning of the February Revolution of 1917, differed from the previous one in its politicization caused by the emergence of political parties in the early $\mathrm{XX}$ century, their legalization during the period of the Russian bourgeois-democratic revolution of 1905-1907 and the desire of women to gain access to political control on a level with men; secondly, there was an increase in the ranks of the participants in the women's movement in Naddnipryan Ukraine and the consolidation of women's associations; thirdly, the liberal democratic and social democratic trends in the women's movement of the Nadnipryan Ukraine were clearly distinguished, that during the years of the Russian bourgeois-democratic revolution of $1905-1907$, before the proclamation of the 1905 Manifesto they marched on a common revolutionary front, after which they parted ways; fourthly, along with the classical types of women's organizations, societies appear that specialized in the struggle for the political rights of women; fifthly, during the period of the Russian bourgeois-democratic revolution of 1905 - 1907 , as well as the First World War, the women's movement of Naddnipryan Ukraine did not stand aside of these events, but was an active participant in them, taking on additional functions, while talking about its main not forgetting; sixth, the women's movement of Naddnipryansk Ukraine loudly declared itself not only at all-Russian women's meetings, but also in society, demonstrating its experience and actively submitting proposals to local elected bodies to endow women with political rights on an equal basis with men.

Today, the study of women's history, both in general and such a component of it, as the way of achieving gender equality in Ukrainian society, in particular in the state leadership, is insufficient, therefore, requires further research.

\section{Бібліографічний список}

Андрусяк, І.П., 2014. Ідея гендерної рівності у поглядах Михайла Драгоманова. Вісник Харківського національного університету внутрішніх справ, 1, с.5-15.

Білосорочка, С., 2018. Олена Пчілка й Наталія Кобринська як започатковувачки суспільнополітичних рухів українських жінок за гендерну рівність. Актуальні проблеми державного управління, 2, с.73-77.

Богачевська-Хомяк, М., 1995. Білим по білому: Жінки в громадському житті Украӥни, 1884 - 1939. Київ: Либідь.

Добровольська, В.А., 2017. Історико-педагогічні аспекти розвитку вищої жіночої школи України у XIX - першій третині XX століття. Історичний архів. Наукові студіï, 19, c.55-61.

Кобченко, К., 2012. Гендерні зміни в українському суспільстві в сер. XIX - на поч. XX ст. як складова європейських цивілізаційних процесів. Украӥнознавчий альманах, 8, с.271274.

Лобко, Н.В., 2016. До питання про виборчі права жінок у Російській імперії на початку XX ст. Сумська старовина, XLIX, с.43-49.

Міщенко, Д., 2011. Політизація українського жіночого руху наприкінці XIX - на початку ХХ ст. Молода наука-2011. Запоріжжя: Просвіта, 5, с.113-115. 
ISSN 2518-1521 (Online), ISSN 2226-2830 (Print)

ВІСНИК МАРІУПОЛЬСЬКОГО ДЕРЖАВНОГО УНІВЕРСИТЕТУ

СЕРІЯ: ІСТОРІЯ. ПОЛІТОЛОГІЯ, 2020, ВИП. 28-29

Нестерцова-Собакарь, О.В., 2016. Правове становище жінки на українських землях у складі Російської імперї у другій половині XIX - на початку XX cm. Дніпро: Дніпропетровський державний університет внутрішніх справ.

Олійник, Н.Ю., 2013. Особливості залученості жінок у громадсько-політичні процеси (середина XIX ст. - початок XX ст.). Гілея: науковий вісник, 72, с.75-80.

Петришина, Л.В., 2016. Гендерні особливості українського національного руху XIX початку XX ст. Науковий вісник Міжнародного гуманітарного університету. Історія. Філософія. Політологія, 2, с.14-19.

Потапюк, Л.М., 2015. Діяльність жіночих громад в Україні як джерело забезпечення гендерного паритету (друга половина XIX - перша третина XX століття). Наукові записки Тернопільського національного педагогічного університету ім. Володимира Гнатюка. Серія : Педагогіка, 1, с.18-23.

Сірополко, С.О., 2001. Історія освіти в Украӥні. Київ: Наук. думка.

Слюсаренко, А.Г., Гусєв, В.І. та Литвин, В.М., 2002. Новітня історія Украӥни (1900 - 2000). 2-ге видання. Київ: Вища школа.

Смоляр, Л.О., ред., 1999. Жіночі студї̈ в Україні: Жінки в історії та сьогоденні. Одеса: Астропринт.

Сташин, I.O., 2008. Феміністичний рух країн Заходу та жіночий рух в Україні: екскурс в минуле. Мова і культура, VI(10), с.166-173.

Фатхутдінова, І., 2015. Роль української жінки в сім’ї та суспільстві. Вісник ХНПУ імені $Г$. С. Сковороди "Філософія", 45(1), с.62-84. DOI: https://doi.org/10.5281/zenodo.22405

Шевченко, М.I., 2013. Соціально-правовий статус Української жінки кінця XIX - поч. XX ст. Культура і мистецтво у сучасному світі, 14, с.129-134.

Яценко, Л., 2008. Жіночий рух України: етапи становлення. Наукові записки з української icmopiï, 21, c.386-390.

\section{References}

Andrusiak, I.P., 2014. Ideia hendernoi rivnosti u pohliadakh Mykhaila Drahomanova [Idea of gender equality in the views of Mykhailo Drahomanov]. Bulletin of Kharkiv National University of Internal Affairs, 1, pp.5-15.

Bilosorochka, S.I., 2018. Olena Pchilka y Nataliia Kobrynska yak zapochatkovuvachky suspilnopolitychnykh rukhiv ukrainskykh zhinok za hendernu rivnist [Olena Pchilka and Nataliia Kobrynska as initiators of ukrainian feminist socio-political movements for gender equality]. Pressing Problems of Public Administration, 2, c.73-77.

Bogachevska-Khamyak, M., 1995. Bilym ро bilomu: Zhinky v hromadskomu zhytti Ukrainy, 1884 - 1939 [White on white. Women in the public life of Ukraine. 1884-1939]. Kyiv: Lybid.

Dobrovolska, V., 2017. Istoryko-pedahohichni aspekty rozvytku vyshchoi zhinochoi shkoly Ukrainy u XIX - pershii tretyni XX stolittia [Historical and pedagogical aspects of developing higher women's education in ukraine in XIX-th - the thirties of XX-th century]. Historical archive. Scientific research, 19, pp.55-61.

Fatkhutdinova, I., 2015. Rol ukrainskoi zhinky v simi ta suspilstvi [The role of Ukrainian women in the family and society]. Visnik Harkivs'Kogo Nacional'Nogo Pedagogičnogo Universitetu imeni G.S. Skovorodi. Filosofiâ, 45(1), pp.62-84. DOI: https://doi.org/10.5281/zenodo.22405

Kobchenko, K., 2012. Genderni zminy v ukrainskomu suspilstvi v ser. XIX-na poch. XX st. yak skladova yevropeiskykh tsyvilizatsiinykh protsesiv [Gender changes in Ukrainian society 
ISSN 2518-1521 (Online), ISSN 2226-2830 (Print) ВІСНИК МАРІУПОЛЬСЬКОГО ДЕРЖАВНОГО УНІВЕРСИТЕТУ СЕРІЯ: ІСТОРІЯ. ПОЛІТОЛОГІЯ, 2020, ВИП. 28-29

in the middle of the XIX-beginning of the XX century as a component of European civilizational processes]. Ukrainoznavchyi almanakh, 8, pp.271-274.

Lobko, N.V., 2016. Do pytannia pro vyborchi prava zhinok u Rosiiskii imperii na pochatku XX st. [On the question of the voting rights of women in the Russian empire atthe beginning ofthe XX century]. Ancient Sumy Land, XLIX, pp.43-49.

Mishchenko, D., 2011. Polityzatsiia ukrainskoho zhinochoho rukhu naprykintsi XIX - na pochatku $\mathrm{XX}$ st. [Politicization of the Ukrainian women's movement in the late nineteenth - early twentieth century]. Young Science - 2011. Zaporozhye: Prosvita, 5, pp.113-115.

Nestertsova-Sobakar, O.V., 2016. Pravove stanovyshche zhinky na ukrainskykh zemliakh u skladi Rosiiskoi imperii u druhii polovyni XIX-na pochatku XX st. [Legal status of a woman in Ukrainian lands being a part of Russian Empire in the latter half of XIX - in early of XX centuries]. Dnipro: Dnipropetrovsk State University of Internal Affairs.

Oliynik, N.Yu., 2013. Osoblyvosti zaluchenosti zhinok u hromadsko-politychni protsesy (seredyna XIX st. - pochatok XX st.) [Features involvement of women in social and political processes (middle XIX - beginning XX centuries)]. Gileya: scientific bulletin, 72, pp.7580.

Petrishina, L.V., 2016. Henderni osoblyvosti ukrainskoho natsionalnoho rukhu XIX - pochatku XX st. [Gender features of the Ukrainian national movement of the XIX - early XX centuries]. Naukovyi visnyk Mizhnarodnoho humanitarnoho universytetu. Seriia: Istoriia. Filosofiia. Politolohiia, 2, pp.14-19.

Potapiuk, L.M., 2015. Diialnist zhinochykh hromad v Ukraini yak dzherelo zabezpechennia gendernoho parytetu (druha polovyna XIX - persha tretyna XX stolittia) [The activity of the women's communities in Ukraine as a source of security of gender parity (the second half of the 19th - the first third of the 20th century)]. The Scientific Issues of Ternopil Volodymyr Hnatiuk National Pedagogical University. Series: pedagogy, 1, pp.18-23.

Shevchenko, M.I., 2013. Sotsialno-pravovyi status Ukrainskoi zhinky kintsia XIX - poch. XX st. [Socio-legal status of the Ukrainian woman of the end of XIX - the beginning. XX century]. Culture and Arts in the Modern World, 14. pp.129-134.

Siropolko, S.O., 2001. Istoriia osvity v Ukraini [History of education in Ukraine]. Kyiv: Naukova Dumka.

Sliusarenko, A.H., Husiev, V.I. and Lytvyn, V.M., 2002. Novitnia istoriia Ukrainy (1900-2000) [Recent history of Ukraine (1900-2000)]. 2nd edition. Kyiv: Vyshcha shkola.

Smoliar, L.O., ed., 1999. Zhinochi studii v Ukraini: Zhinky v istorii ta sohodenni [Women's Studios in Ukraine: Women in History and Present]. Odessa: Astroprint.

Stashyn, I.O., 2008. Feministychnyi rukh krain Zakhodu ta zhinochyi rukh v Ukraini: ekskurs v mynule [Feminist movement of Western countries and the women's movement in Ukraine: an excursion into the past]. Language and culture, VI(10), pp.166-173.

Yatsenko, L., 2008. Zhinochyi rukh Ukrainy: etapy stanovlennia [Women's movement of Ukraine: stages of formation]. Scientific notes on Ukrainian history, 21, pp.386-390.

Стаття надійшла до редакції 10.10.2020 p. 


\section{В. К. Мотуз \\ ІСТОРІЯ ПЕРЕТВОРЕННЯ ЖІНОК НАДДНІПРЯНСЬКОЇ УКРАЇНИ 3 ОБ'ЄКТА В СУБ'ЄКТ ПОЛІТИЧНОГО ПРОЦЕСУ: ВІД ІДЁ̈ ДО ПРАКТИЧНОГО ВТІЛЕННЯ}

У статті обгрунтовується теоретичні та практичні засади розвитку жіночого руху в Наддніпрянській Україні в умовах активної політизації суспільства кінця XIX - початку ХХ століття. Де об'єктом дослідження виступає підвищення жінкою з Наддніпрянської Украӥни свого соціального статусу в суспільстві, а предметом - ї̈ перетворення в суб'єкт політичної діяльності. Цей прочес розкривається з позиції впливу політизації украӥнського суспільства кіния XIX - початку XX століття на рух соціально активних жінок Наддніпрянської України в напрямку досягнення модернізації системи влади та управління з точки зору гендерної рівності та репрезентується як перехідний етап до иього. Мета даної статті - висвітлити ключовий етап у розвитку жіночого руху в Наддніпрянській Україні, в ході якого не лише відбулась його політизачія, а й сформувалась опора для подальшого просування жінок у таку важливу складову публічної сфери життя суспільства як державне управління. Методологічні засади дослідження. Для досягнення цієї мети автором були застосовані принциипи науковості, об’єктивності, історизму, системності, иілісності та детермінізму. Наукова новизна. У иій статті вперше у вітчизняній історіографії розглядається проблема перетворення жінок Наддніпрянської Украӥни з об'єкта в суб'єкт політичного прочесу та його результати. Висновки. Досліджуючи проблему перетворення жінок Наддніпрянської України з об'єкта в суб'єкт політичної діяльності, автор наукової розвідки дійшов висновків, щцо кінець XIX - початок ХХ століття є проміжним етапом в історії розвитку жіночого руху в Украӥні, який безпосередньо пов'язаний із зародженням та реалізацією ідеї щуодо отримання жінками доступу до політичного управління нарівні з чоловіками, який вони здобудуть вже на початку наступного етапу розвитку руху - в березні 1917 року. Активна політизачія суспільства в Наддніпрянській Україні в кінці XIX - на початку XX століття, засоби та методи, які використовували представниці жіночого руху Наддніпрянської України задля отримання політичних прав, значний досвід участі у громадському житті Російської імперії та Наддніпрянської Украӥни зокрема, шанобливе ставлення до жінки в украӥнському суспільстві - все це варто розглядати як передумови та иляхи подолання останньої перепони для жінок в публічній сфері життя українського суспільства - відсутності доступу до державного управління. Перспективи подальших розвідок у даному напрямку. Сьогодні вивчення жіночої історії як в цілому, так і такої ї̈ складової, як шлях досягнення гендерної рівності в украӥнському суспільстві, зокрема в державному керівництві, $\epsilon$ недостатнім, тому вимагає подальших досліджень. Наприклад, висвітлення передумов та причин світоглядних трансформацій українського суспільства кіния XIX - початку XX століття щуодо необхідності наділення жінок Наддніпрянської України політичними правами.

Ключові слова: жінка, жіноча історія, жіночий рух, жіночий рух у Наддніпрянській Україні кінця XIX - початку XX століття, суспільство, украӥнське суспільство, політизаџія українського суспільства в кінці XIX-на початку XX століття 